\title{
THE EFFECT OF MOTIVATION AND WORK DISCIPLINE ON EMPLOYEE PERFORMANCE
}

\author{
Winda Nurmayanti ${ }^{* 1}$, Enang Narlan SAP ${ }^{2}$ \\ Universitas Langlangbuana, Indonesia*12 \\ windanurmayanti6@gmail.com*1, enangnsap@gmail.com²
}

\begin{abstract}
Human resources have a major role in every organizational activity for the achievement of company goals. Employee performance levels need to be considered to achieve high productivity. Therefore this research was conducted wherein the pre-survey there were problems, especially in terms of motivation, work discipline, and employee performance, especially at Perum Jamkrindo Bandung Branch Office, and to determine the extent of the influence of motivation and work discipline on employee performance at Perum Jamkrindo Branch Offices Bandung. The method used in this research is the census method where this study takes the entire population of employees of the Jamkrindo Bandung Branch Office to become respondents. The data collected is using questionnaires and interviews. The questionnaire was distributed to 45 respondents and the data processing from the study used path analysis. The motivation variable can be stated in the good category and runs optimally. Likewise, work discipline variables are in a good category for employees as well, and employee performance variables are in a good category and have an effect on productivity at Perum Jamkrindo Bandung Branch Office. Motivation and Work Discipline have a significant relationship, employee motivation and performance have an influence, although not quite large, and work discipline on employee performance also has a greater influence.
\end{abstract}

Kata Kunci: Motivation, Work Discipline, Employee Performance

\section{INTRODUCTION}

Along with the current era of globalization and in the conditions of today's society, there are often problems that cause many organizations to fail, either due to technological advances or inability to adapt due to poor work results from the existing human resources in the organization. According to Fahmi (2016) "Human resource management is a series of organizational activities directed at developing, attracting and maintaining an effective workforce".

Human resources have a major role in every organizational activity. The success or failure of an organization or institution in achieving a goal will be determined by human factors or the employees themselves in carrying out their duties. Employees are required to be able to show good performance following the company or organizational regulations. An employee who has high and good performance can support the achievement of the goals and objectives set by the organization. Kasmir (2016) states that performance is the result of a person's work and work behavior in a period, usually 1 year. Then performance can be measured by its ability to complete the tasks and responsibilities given. Employees who want to get a good performance, then their behavior is directed in the form of work and high morale, making optimal use of their abilities and skills, so that maximum performance is obtained. The employee performance appraisal system is the work of employees within the scope of their responsibilities which of course refers to a formal system and structure that is used as an instrument to measure employee performance, assess and influence work-related characteristics, control employee behavior, including absenteeism levels, work results. , giving bonuses, promotions, and placing employees in appropriate positions. Increased knowledge, abilities, and 
changes in attitudes are needed to improve performance through motivation and work discipline from the leadership.

Sedarmayanti (2017) states that motivation is a force that encourages someone to take any action or not, which essentially exists internally and externally, positive or negative to direct it, very much depends on the toughness of the leadership. Meanwhile, according to Priansa (2014), states that "Motivation is the driver of employee behavior". The formation of the achievement motive is very complex, as complex as the development of the human personality. This motive cannot be separated from the development of the personality, and never develops in a vacuum. Motivation to work is very important for the high and low productivity of the company. Without motivation from employees to work together for the benefit of the company, the goals that have been set will not be achieved.

Work discipline is a tool used by managers to communicate with employees so that they are willing to change behavior and as an effort to increase one's awareness and willingness to obey all company regulations and prevailing social norms. Ganyang (2018) states that "Discipline is a condition in which employees are willing to accept and implement various existing regulations, both those that are expressed in a concrete manner or habits that have become a culture, and are related to the implementation of duties, powers, and responsibilities towards the company".

Marpaung, et al (2014) stated that motivation and work discipline are important factors that affect employee performance. Motivation and work discipline instilled by the organization or company to employees will greatly affect the sincerity of employees in working. Therefore, the leader of the organization or company must be able to provide the motivation that can encourage employees to work actively and make employees work in a disciplined manner.
The Indonesian Public Credit Guarantee Company (Perum Jamkrindo) is a credit guarantee company in Indonesia which is a StateOwned Enterprise (BUMN) which focuses on the credit guarantee business on micro, small and medium enterprises and cooperatives (UMKMK). Perum Jamkrindo which is located at Soekarno Hatta Street, KM. 12 No. 722 Bandung is required to be able to improve the performance and quality of good services accompanied by an attitude of high enthusiasm and work discipline in the work environment. Employee performance improvement needs to be continuously developed to have high abilities, skills, and insights which ultimately can meet the needs of the organization as a process of achieving goals, therefore motivation and work discipline of employees need to be improved in the Indonesian Public Credit Guarantee Corporation (Perum Jamkrindo).

Interviewing with one of the employees at the company, current efforts to improve the performance of the staffing department are continuously being improved, one of which is ordering a high discipline with existing regulations so that employees act accordingly so that employees can improve their discipline. Motivation is also very important because it affects performance results. The cause of the decrease in motivation given by the company. Also, the authors see several problems that occur such as: Regarding employee performance at Perum Jamkrindo, it is suspected that there are still problems that need to be addressed, namely: (1) In terms of quality, it is seen that there are still employees who do not maintain and pay less attention to work quality so that employees work. carelessly; (2) In terms of quantity, it can be seen that there are still employees who have not made efforts to achieve work targets. Work targets that do not reach according to demand. For example, an employee who can 
complete one day's data recap does not finish in one day.

As one of the factors behind the problem of performance, it can be seen from the motivation of employees who are suspected of having problems within the employee, namely: (1) Employees still lack high motivation because the company rarely provides feedback on the employee's skills at work; (2) Still coordinating between employees in their work

Other factors underlying the problems of performance are employee work discipline, which shows that there are still problems that need to be addressed, namely: (1) The level of employee compliance with regulations is still lacking; (2) Discipline towards time is still lacking, such as late entry at work time and break time is over.

The problems that have been discussed show that the problems of motivation and work discipline need serious attention to improve employee performance. Therefore, this research was conducted to know and analyze the motivation, work discipline, and performance of employees, especially at Perum Jamkrindo Bandung Branch Office, as well as to determine the extent of the influence of motivation and work discipline on employee performance at
Perum Jamkrindo Bandung Branch Office.

\section{METHODS}

The method used in this research is the census method where this study takes the entire population of employees of Perum Jamkrindo Bandung Branch Office to become respondents. The data collected is using questionnaires and interviews. The questionnaire was distributed to 45 respondents and the data processing from the study used path analysis. In this research, Path analysis and hypothesis testing will be carried out

\section{RESULTS AND DISCUSSION Analysis of the Partial Influence of Motivation on Performance}

Path analysis is used to see the direct and indirect effects of a set of variables, as the causal variable (X1) on other variables which are the result $(Y)$ because the method used is the path analysis method, it is necessary to calculate the Pearson Correlation Coefficient. This is done first to be able to see the relationship between variable $\mathrm{X} 1$ and variable $\mathrm{X} 2$, namely $\mathrm{rx} 1 \times 2$. The following is the result of calculating the Pearson Correlation Coefficient using SPSS ver 23 Software.

Table 1. Correlation Between Variables X1 and X2

\begin{tabular}{ccccc}
\hline & & Correlations & \\
& & $\mathrm{x} 1$ & $\mathrm{x} 2$ & $\mathrm{y}$ \\
\hline $\mathrm{x} 1$ & Pearson Correlation & 1 & $.765^{* *}$ & $.765^{* *}$ \\
& Sig. (2-tailed) & & .000 & .000 \\
$\mathrm{~N}$ & 45 & 45 & 45 \\
$\mathrm{x} 2$ & Pearson Correlation & $.765^{* *}$ & 1 & $.885^{* *}$ \\
& Sig. (2-tailed) & .000 & & .000 \\
& $\mathrm{~N}$ & 45 & 45 & 45 \\
$\mathrm{y}$ & Pearson Correlation & $.765^{* *}$ & $.885^{* *}$ & 1 \\
& Sig. (2-tailed) & .000 & .000 & \\
& $\mathrm{~N}$ & 45 & 45 & 45 \\
\hline \multicolumn{2}{c}{ Source: Data Processed by the author using SPSS Version 23 (2020) }
\end{tabular}


Based on table 1 above, it can be seen that the closeness of the relationship between variables $\mathrm{X} 1$ and $\mathrm{X} 2$ as stated by the magnitude of the correlation coefficient ( $r \times 1 \times 2)$ is 0.765 which is categorized as strong, meaning that there is a significant relationship between variables $\mathrm{X} 1$ and $\mathrm{X} 2$ which will later be used in calculating the coefficient of determination., to calculate the amount of indirect effect from the causal variable to the effect variable. Based on calculations using SPSS ver 23 software, it can be seen that the path coefficient results are as follows:

Table 2. Partial Test Results

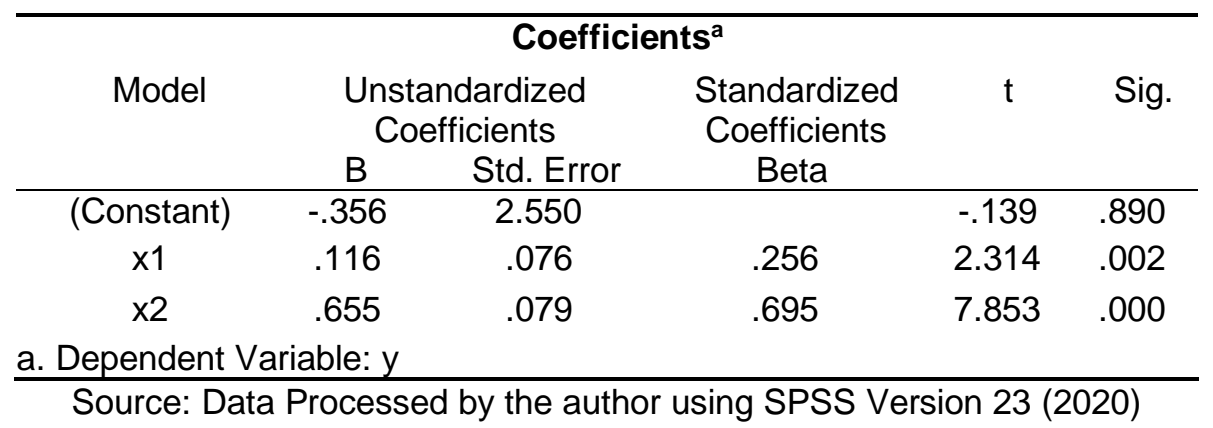

In the Coefficients table above, in the Standardized Coefficients column, there are respective variable path coefficients $X 1$ and $X 2$ against $Y$. The variable path coefficient of Motivation (X1) on Employee Performance ( $\mathrm{Y}$ ) is pyx 1 is 0.256 or $25.6 \%$, which means that there is a significant influence. very small between motivation (X1) on Employee Performance $(Y)$.

The amount of direct influence, indirect effect, and total effect. Motivation Variable (X1) on Employee Performance $(Y)$ can partially be calculated by observing the following table and equation:

Direct Influence:

$=(\rho y x 1) 2$

$=(0.256) 2$

$=0.066 / 6.6 \%$

Effect through correlation with $\mathrm{X} 2$ :

$=$ pyx $1 \times \mathrm{rx} 1 \times 2 \mathrm{X}$ pyx 2

$=(0.256) \times(0.765) \times(0.695)$

$=0.136 / 13.6 \%$

The total effect of $\mathrm{X} 1$ on $\mathrm{Y}$ :

$=0.066+0.136$

$=0.202 / 20.2 \%$

From the above equation, the magnitude of the influence of Motivation
(X1) which directly determines changes in Employee Performance $(\mathrm{Y})$ is 0.066 $(6.6 \%)$ and that through its relationship with Discipline (X2) is 0.136 (13.6\%). Thus the effect of motivation (X1) on employee performance $(\mathrm{Y})$ partially is the amount of total or combined influence of direct and indirect effects (X1) on (Y), $0.066+0.136=0.202$ or $20.2 \%$, meaning partial motivation. effect on Employee Performance by $20.2 \%$.

\section{Analysis of the Partial Influence of Work Discipline on Employee Performance}

At this stage, the influence of Discipline (as an independent variable or X2) and Employee Performance (as the dependent variable or $Y$ ) will be analyzed using statistical tests. Path analysis is used to determine the direct and indirect effects of a set of variables, as a variable that causes Discipline (X2) to other variables that are a result of Employee Performance ( $\mathrm{Y}$ ).

Based on calculations using SPSS ver 23 software, it can be seen that the path coefficient results are as follows: 
Table 3. Partial Test Results

\begin{tabular}{|c|c|c|c|c|c|c|}
\hline \multicolumn{7}{|c|}{ Coefficients $^{a}$} \\
\hline & \multirow[t]{2}{*}{ Model } & \multicolumn{2}{|c|}{$\begin{array}{l}\text { Unstandardized } \\
\text { Coefficients }\end{array}$} & \multirow{2}{*}{$\begin{array}{l}\text { Standardized } \\
\text { Coefficients } \\
\text { Beta }\end{array}$} & \multirow[t]{2}{*}{$\mathrm{t}$} & \multirow[t]{2}{*}{ Sig. } \\
\hline & & B & Std. Error & & & \\
\hline \multirow[t]{3}{*}{1} & (Constant) & -.356 & 2.550 & & -.139 & .890 \\
\hline & $x 1$ & .116 & .076 & .256 & 2.314 & .002 \\
\hline & $\begin{array}{l}x 2 \\
\text { ndent Variak }\end{array}$ & .655 & .079 & .695 & 7.853 & .000 \\
\hline
\end{tabular}

Source: Data Processed by the author using SPSS Version 23 (2020)

In the Coefficients table on the previous page, in the Standardized Coefficients column, there are respective path coefficients for the variables $X 1$ and $X 2$ against $Y$. the influence of Discipline (X2) on Employee Performance $(\mathrm{Y})$.

The amount of direct influence, indirect effect, and total effect. Discipline Variable (X2) on Employee Performance (Y) can partially be calculated by observing the following table and equation:

Direct Influence:

$=(\rho y \times 2) 2$

$=(0.695) 2$

$=0.483 / 48.3 \%$

Influence through correlation:

$=\rho y x 1 \times r \times 1 \times 2 \times \rho y \times 2$

with $\mathrm{X} 1$

$=(0.256) \times(0.765) \times(0.695)$

$=0.136 / 13.6 \%$

The total effect of $\mathrm{X} 2$ on $\mathrm{Y}$ :

$$
=0.483+0.136
$$$$
=0.619 / 61.9 \%
$$

From the above equation, the magnitude of the influence of Discipline (X2) which directly determines changes in Employee Performance $(\mathrm{Y})$ is 0.483 $(48.3 \%)$ and that through its relationship with Motivation (X1) is 0.136 (13.6\%). Thus the effect of Work Discipline (X2) on Employee Performance (Y) partially is the amount of total or combined influence of direct and indirect effects $(\mathrm{X} 1)$ on $(\mathrm{Y}), 0.483+0.136=0.619$ or $61.9 \%$, meaning Work Discipline partially affect the employee performance of $61.9 \%$.

\section{Analysis of the Effect of Motivation and Work Discipline on Employee Performance Simultaneously}

Table 4. Simultaneous Test Results

\begin{tabular}{|c|c|c|c|c|c|c|}
\hline \multicolumn{7}{|c|}{ ANOVA $^{a}$} \\
\hline & Model & $\begin{array}{l}\text { Sum of } \\
\text { Squares }\end{array}$ & df & Mean Square & $\mathrm{F}$ & Sig. \\
\hline \multirow[t]{3}{*}{1} & Regression & 1133.485 & 2 & 566.743 & 78.158 & .05 \\
\hline & Residual & 292.719 & 42 & 6.969 & & \\
\hline & Total & 1426.204 & 44 & & & \\
\hline & $\begin{array}{l}\text { ependent V } \\
\text { redictors: (C }\end{array}$ & $\begin{array}{l}y \\
n t), x 2, x 1\end{array}$ & & & & \\
\hline
\end{tabular}


In the ANOVA table, an $\mathrm{F}$ value of 78.158 is obtained with a probability value $(\mathrm{sig})=0.05$, because the value of Fcount> Ftable (78.158> 3.22), the decision is:

Based on the simultaneous hypothesis calculation ( $f$ test) the effect of motivation and work discipline on employee performance, the F-count is 78.158 and F-table is 3.22 . Following the calculation criteria if Fcount> Ftable, then $\mathrm{H} 0$ is rejected and $\mathrm{H} 1$ is accepted. It shows that motivation and work discipline has a significant effect on the employee performance of Perum Jamkrindo.

Table 5. Coefficient of Determination

\begin{tabular}{ccccc}
\hline Model & $\mathrm{R}$ & $\mathrm{R}$ Sodel Summary & \\
& & Adjusted R & Square & $\begin{array}{c}\text { Std. Error of the } \\
\text { Estimate }\end{array}$ \\
\hline 1 & $.891^{\mathrm{a}}$ & .821 & .785 & 2.63998 \\
a. Predictors: (Constant), $\mathrm{x} 2, \mathrm{x} 1$ & & \\
\hline \multicolumn{3}{l}{ Source: Data Processed by the author using SPSS Version $23(2020)$}
\end{tabular}

The magnitude of the coefficient of determination or the combined effect of $\mathrm{X} 1$ and $\mathrm{X} 2$ to $\mathrm{Y}$ which is none other than the magnitude of $R$ Square is 0.821 as in the Model Summary table above, so the value of $R$ Square is entered into the formula to obtain the residual variable value as below:

Namely py $\varepsilon=(1-0.821)=0.179$

Therefore it can be interpreted that Motivation and Work Discipline jointly influence Employee Performance by $82.1 \%$ (R-Square) and are influenced by other factors not examined at $17.9 \%$ while the magnitude of the influence received by Employee Performance ( $Y$ ) from Motivation (X1) and Work Discipline (X2) as well as all variables outside (X1) and (X2) which are expressed by the residual variable $(\varepsilon)$ is $\mathrm{r} 2 \mathrm{yx} 1 \mathrm{x} 2+\rho \mathrm{y} \varepsilon=82.1 \%+17.9 \%=$ $100 \%$.

\section{CONCLUSION}

Motivation at Perum Jamkrindo Bandung Branch Office is good, but there are still things that are lacking, among others: The level of need for food and beverage employees, the need for employee clothing, the need for employee housing, the level of need to be part of the company, the level of coordination with colleagues, feedback from the company, the opportunity to provide advice and assessment.

Work discipline at Perum Jamkrindo Bandung Branch Office is good, but there are still things that are lacking, among others: Company objectives that are stated in writing, there are still many employees who have not obeyed the rules in the company, the level of behavior of superiors in obeying company regulations, the level of behavior of superiors be an example of discipline for employees and the level of rewards given to disciplined employees.

The performance at Perum Jamkrindo Bandung Branch Office is good, but there are still things that are lacking, among others: The level of quantity of work results, employees have not carried out their duties properly following the main duties and functions, the level of full responsibility for the work assigned to improve performance and independence in doing work independently without depending on others. 


\section{REFERENCES}

Fahmi. Irham. (2016). Manajemen Sumber Daya Manusia (Teori dan Aplikasi). Bandung: Alfabeta

Kasmir. (2016). Manajemen Sumber Daya Manusia (Teori dan Praktik). Depok: PT Rajagrafindo Persada

Priansa. Donni Juni. (2014). Perencanaan \& Pengembangan SDM. Bandung: Alfabeta.

Marpaung, I.M., Hamid, D. \& Iqbal, M. (2014). Pengaruh Motivasi dan Disiplin Kerja Terhadap Kinerja Karyawan. Jurnal Administrasi Bisnis (JAB). 15(2), 1-8.
Sedarmayanti. (2017). Perencanaan dan Pengembangan Sumber Daya Manusia (untuk meningkatkan kompetensi, kinerja, dan produktivitas kerja. Bandung: PT Refika Aditama.

Ganyang, Machmed, Tun. (2018). Manajemen Sumber Daya Manusia Konsep dan Realita. Bogor: IN MEDIA. 